\title{
Assessing metal recovery from low-grade copper ores containing fluoride
}

\author{
Lázaro Sicupira, Tácia Veloso, Flávia Reis, Versiane Leão*

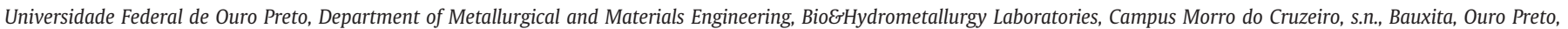 \\ MG, 35400-000, Brazil
}

\section{A R T I C L E I N F O}

\section{Article history:}

Received 10 May 2011

Received in revised form 13 July 2011

Accepted 14 July 2011

Available online 22 July 2011

\section{Keywords:}

Bioleaching

Sulfobacillus thermosulfidooxidans

Aluminium

Fluoride

Secondary copper sulphides

\begin{abstract}
A B S T R A C T
Low-grade ores are becoming increasingly important to metal production due to increasing metal prices and depletion of high-grade, low-impurity sources. Bioleaching can be an option to recover the metallic content present in these tailings. In this work, the bioleaching potential of a low-grade copper ore, containing chalcocite, bornite and chalcopyrite, was demonstrated with a Sulfobacillus thermosulfidooxidans strain, at $50{ }^{\circ} \mathrm{C}$. Batch experiments were performed in shake flasks as well as a bioreactor (BioFlo 110), and the effects of $\mathrm{pH}$, metal concentration and air flow rate on copper extraction were determined. The presence of fluoride in the gangue minerals resulted in up to $270 \mathrm{mg} / \mathrm{L}$ total fluoride in solution, which affected bioleaching. Fluoride toxicity was overcome with aluminium additions and resulted in high copper extraction (up to $100 \%$ ) at $\mathrm{pH}$ 1.9. Speciation calculations were performed with on the aluminium-fluoride systems and indicated $\mathrm{AlF}^{2+}$ as the main complex in the system, whereas HF concentration was reduced to values below $10^{-4} \mathrm{~mol} / \mathrm{L}$, which seems to be the threshold for bacterial growth inhibition.
\end{abstract}

(c) 2011 Elsevier B.V. All rights reserved.

\section{Introduction}

The extractive metallurgy industry is facing the challenge of processing low-grade ores, which often contain deleterious elements in their gangue. Bioleaching can be an option to recover the metallic content present in these materials (Habashi, 1993). Copper is one of such metals, as it has recently achieved record high prices, which facilitated the processing of these low-grade sources in a costeffective way. In this regard, bioleaching is one of the technologies available for the processing of such ores.

Secondary copper sulphides are especially amenable to bioleaching since high extractions at relatively fast kinetics can be achieved. Witne and Phillips (2001) assessed the performance of a mixed copper concentrate (chalcopyrite, bornite, chalcocite, covellite) during bioleaching with mesophiles (Acidithiobacillus ferrooxidans), moderate thermophiles (Sulfobacillus acidophilus) and extreme thermophiles (Sulfolobus strain BC65). Bioleaching achieved 76\% extraction with $A$. ferrooxidans; $78 \%$ with S. acidophilus $\left(50{ }^{\circ} \mathrm{C}\right)$ and $85 \%$ with Sulfolobus, at $70{ }^{\circ} \mathrm{C}$ (50\% extraction in the control test). Bioreactor experiments at $3 \%(\mathrm{w} / \mathrm{v})$ pulp density with the three microorganisms showed optimum extractions with $0.5 \mathrm{~L}$-air/min air flow rate, producing average dissolved oxygen concentrations in the pulps higher than $3.5 \mathrm{mg} / \mathrm{L}$. Overall, the copper leaching rate increased by up to $30 \%$ as compared to the shake flask runs and

\footnotetext{
* Corresponding author at: Bio\&Hydrometallurgy Laboratories, Department of Metallurgical and Materials Engineering, Campus Morro do Cruzeiro, s.n., Bauxita, Ouro Preto, MG, 35400-000, Brazil. Tel.: +55 313559 1102; fax: + 553135591561.

E-mail addresses: versiane@demet.em.ufop.br, versiane.ufop@gmail.com (V. Leão).
}

among the three type of strains, the moderate thermophiles performed better, showing higher copper leaching rates.

Column bioleaching experiments carried out with an ore in which $80 \%$ of the copper was covellite showed different behaviour with both mesophilic and thermophilic microorganisms (Acar et al., 2005). One column, inoculated with a mixed culture containing Acidianus and Metallosphaera strains at $65^{\circ} \mathrm{C}$, produced $75 \%$ copper extraction, in 345 days, whereas in those columns containing mesophilic bacteria (A. ferrooxidans and $L$. ferrooxidans), at $20-23{ }^{\circ} \mathrm{C}$, less than $20 \%$ copper extraction was observed. Ferric iron was the predominant species in the column with mesophiles, but up to $15 \mathrm{~g} / \mathrm{L} \mathrm{Fe}^{2+}$ was observed in the experiments with thermophiles (at $65^{\circ} \mathrm{C}$ ), since these microorganisms do not oxidize $\mathrm{Fe}^{2+}$ as fast as mesophiles. Recently, Lee et al. (2011) compared the bioleaching performance of three different samples of the same ore, each one containing either chalcocite or covellite or enargite, as the predominant sulphide. The chalcocite rich sample was bioleached by both mesophilic and thermophilic strains with copper extractions ranging from $89.9 \%$ to $99.2 \%$. The covellite sample was leached only with thermophiles $(88.3-95.4 \%$, in 300 days), and under mesophilic conditions copper extraction was lower than 20\% (in 240 days). These results are consistent with previous studies on mixed sulphide bioleaching, which indicated slower covellite dissolution as compared to the chalcocite-containing column (Olson and Clark, 2001).

During ore bioleaching the gangue minerals may play an important role on bioleaching performance. Although the microorganisms can be adapted to high metal concentrations, anionic species present in the gangue minerals can impact bioleaching even at low concentrations (Suzuki et al., 1999). The effects of anions such as 
sulphate, nitrate, cyanide, chloride on both ferrous iron and sulphur oxidation have been assessed, specially with mesophiles (Suzuki et al., 1999). Sulphate has the smallest detrimental effect on bioleaching, while low concentrations of chloride, cyanide, nitrate and fluoride are detrimental to bacterial growth and therefore to bioleaching. Specifically, A. ferrooxidans growth on elemental sulphur was inhibited by sodium fluoride $(\mathrm{NaF})$, and calcium fluoride was shown to reduce cell counts to values lower than the detection limit on experiments aiming to inhibit acid mining drainage production (Schippers et al., 1996).

In addition to fluorite and fluorapatite, fluoride can be also associated with silicate minerals such as muscovite $\left(\mathrm{KAl}_{3} \mathrm{Si}_{3} \mathrm{O}_{10}(\mathrm{OH})_{2}\right)$ and biotite $\left(\mathrm{KFeMg}_{2} \mathrm{AlSi}_{3} \mathrm{O}_{10}(\mathrm{OH})_{2}\right)$. During column bioleaching of a chalcopyrite ore in which the main gangue minerals were silicates, Dopson et al. (2008) detected total fluoride concentrations as high as $300 \mathrm{mg} / \mathrm{L}$, which affected bacterial growth. That resulted in low Eh values $(420 \mathrm{mV})$ and high ferrous iron concentrations during bioleaching. Nevertheless, aluminium dissolved from the ore complexed free fluoride, reducing HF concentration and its detrimental impact on bioleaching.

This work reports results from a secondary sulphide ore bioleaching with a moderate thermophilic strain (Sulfobacillus thermosulfidooxidans) in the presence of fluoride ions. The effects of $\mathrm{pH}$, magnesium, particle size and on copper extraction as well as aluminium- fluoride speciation are discussed.

\section{Experimental}

\subsection{Ore samples}

The bioleaching experiments were carried out with two secondary sulphide ore samples (Table 1 ). The first sample contains $0.9-1.43 \%$ copper and the second, $0.66-1.06 \%$. Both ores will be henceforth referred to as high-copper and low-copper ores, respectively.

Mineralogical analysis - performed by optical microscopy as well as SEM-EDS and supported by chemical analysis - indicates that the high-grade copper ore sample contains biotite (42.3\%), magnetite (21.5\%) and silicates, specially amphibole (18.9\%) and garnet (6.9\%). In addition, the low-grade copper ore presents roughly the same amount of biotite $(34.9 \%)$ and amphibole $(25.2 \%)$, less magnetite (9.5\%) and more garnet (16.7\%). The copper containing minerals comprise bornite (36\%) as well as chalcocite (64\%) in the high-copper ore, while the low-copper ore contains 39\% bornite, 55\% chalcocite and $6 \%$ chalcopyrite. In both cases, cyanide-soluble copper accounted for $92.2 \%$ of the total copper in the high-copper ore and $85.0 \%$ in the low-copper ore, which is consistent with the mineralogical characterization. Both ores also contain $0.53-0.85 \%$ chloride and $0.53-1.0 \%$ fluoride as fluorite $\left(\mathrm{CaF}_{2}\right)$.

\subsection{Bioleaching experiments}

Bioleaching experiments were performed at $50{ }^{\circ} \mathrm{C}$ with a moderate thermophilic strain (S. thermosulfidooxidans, DSMZ 9293) and bacterial growth was carried out in the Norris medium $(0.2 \mathrm{~g} / \mathrm{L}$
$\left(\mathrm{NH}_{4}\right) \mathrm{SO}_{4}, 0.4 \mathrm{~g} / \mathrm{L} \mathrm{MgSO}_{4} .7 \mathrm{H}_{2} \mathrm{O}$, and $\left.0.1 \mathrm{~g} / \mathrm{L} \mathrm{K} \mathrm{HPO}_{4}\right)$, supplemented with yeast extract (Difco) $(0.1 \mathrm{~g} / \mathrm{L})$. Growth nutrient solution $(50 \mathrm{~mL})$ was adjusted to the required $\mathrm{pH}$ and transferred to $250 \mathrm{~mL}$ Erlenmeyer flasks and the required amount of $\mathrm{Fe}(\mathrm{II})$ was added as an acid solution containing $50 \mathrm{~g} / \mathrm{L} \mathrm{Fe}$ (II) (as $\mathrm{FeSO}_{4} \cdot 7 \mathrm{H}_{2} \mathrm{O}$ ). Afterwards, $5 \mathrm{~g}$ of the ore (corresponding to $5 \%(\mathrm{w} / \mathrm{v})$ pulp density) were added and the flasks were inoculated with a $10 \mathrm{~mL}$ aliquot of the selected culture, containing some $10^{7}$ cells/mL. Finally, distilled water was added to reach a final slurry volume of $100 \mathrm{~mL}$. Subsequently, the $\mathrm{pH}$ was adjusted to the required value, and the flask weight was recorded. A temperature-controlled orbital shaker (New Brunswick) provided mixing $\left(180 \mathrm{~min}^{-1}\right)$. Each flask was sampled by removing a $2 \mathrm{~mL}$ aliquot of the leach solution, which was then used for elemental analysis ( $\mathrm{Cu}$ and $\mathrm{Fe}$ ), by atomic absorption spectrometry (Perkin Elmer, AAnalyst 100) or Inductively Coupled Plasma - Atomic Emission Spectrometry (Varian 725). The pH (Hanna HI931400) was adjusted using $1 \mathrm{~mol} / \mathrm{L}$ sulphuric acid or $6 \mathrm{~mol} / \mathrm{L}$ sodium hydroxide. The redox potential (Digimed) (vs. $\mathrm{Ag} / \mathrm{AgCl}$ reference) was also recorded. Evaporation losses were compensated by the addition of the Norris medium to the recorded weight. Sterile controls were also run in the presence of $0.015 \%(\mathrm{v} / \mathrm{v})$ methylparaben - $0.01 \%(\mathrm{v} / \mathrm{v})$ propylparaben solutions as bactericide.

Aeration experiments were performed in a baffled bioreactor (New Brunswick Scientific - BioFlo 110) with $2 \mathrm{~L}$ of suspension containing 10\% (volume) of inoculum. To produce the latter, $200 \mathrm{~mL}$ of the inoculum were transferred to the bioreactor, and growth medium containing $1 \mathrm{~g} / \mathrm{L} \mathrm{Fe}^{2+}$ (as $\mathrm{FeSO}_{4}$ ) was added to produce a final solution volume of $2 \mathrm{~L}$. The $\mathrm{pH}$ was controlled during the experiments by the addition of either concentrated sulfuric acid or sodium hydroxide. Both the temperature and the stirring rate were maintained at $50{ }^{\circ} \mathrm{C}$ and $300 \mathrm{~min}^{-1}$ (dual rushton-impeller, $5 \mathrm{~cm}$ diameter), respectively.

Initially, bacterial growth in the presence of fluoride and aluminium ions was assessed in the absence of solid material. The aluminium/fluoride molar ratio was varied from 0 to 1.40 ; NaF was used as the fluoride source while aluminium was supplied as $\mathrm{Al}_{2}$ $\left(\mathrm{SO}_{4}\right)_{3} \cdot(14-18) \mathrm{H}_{2} \mathrm{O}$. Following, the effects of $\mathrm{pH}(1.40,1.65,1.90$ and 2.15), particle size $(150-106 \mu \mathrm{m}, 106-75 \mu \mathrm{m}, 75-53 \mu \mathrm{m}, 53-$ $37 \mu \mathrm{m}), \mathrm{Fe}^{2+}$ concentration $(0,1.0,5.0$ and $10.0 \mathrm{~g} / \mathrm{L})$; $\mathrm{Al}^{3+}$ concentration $(0,2.5,5.0$ and $10.0 \mathrm{~g} / \mathrm{L})$ and $\mathrm{Mg}^{2+}$ concentration $(0,2.5,5.0$ and $10.0 \mathrm{~g} / \mathrm{L}$ ) on copper extraction were studied. The total fluoride concentration was determined by an ion chromatograph (Metrohm) using an ASSUP-10 column and conductivity detection. The mobile phase was a $\mathrm{Na}_{2} \mathrm{CO}_{3} / \mathrm{NaHCO}_{3}$ solution.

Cell counts were performed using a Neubauer chamber in a phase contrast microscope (Leica). Ferrous iron concentration was determined by titration with standard potassium dichromate solution in the presence of a $1 \mathrm{H}_{2} \mathrm{SO}_{4}: 1 \mathrm{H}_{3} \mathrm{PO}_{4}$ solution using an automatic titrator (Schott - Tritoline Alpha). All chemicals used in this study were analytical grade reagents (AR) unless otherwise stated, and all solutions were prepared with distilled water.

The morphological features of the leach residues were studied by SEM-EDS with a JEOL JSM 501 SEM microscope. The particles investigated were filtered and observed as powder or mounted in

Table 1

Chemical analysis (\%) of the ore samples studied.

\begin{tabular}{|c|c|c|c|c|c|c|c|c|}
\hline \multirow[t]{2}{*}{ Element } & \multicolumn{4}{|l|}{ Copper ore } & \multicolumn{4}{|l|}{ Marginal ore } \\
\hline & $150-106 \mu \mathrm{m}$ & $106-75 \mu \mathrm{m}$ & $75-53 \mu \mathrm{m}$ & $53-37 \mu \mathrm{m}$ & $150-106 \mu \mathrm{m}$ & $106-75 \mu \mathrm{m}$ & $75-53 \mu \mathrm{m}$ & $53-37 \mu \mathrm{m}$ \\
\hline $\mathrm{Cu}(\%)$ & 0.90 & 0.99 & 1.22 & 1.43 & 0.66 & 0.73 & 0.93 & 1.06 \\
\hline $\mathrm{Fe}(\%)$ & 33.71 & 32.73 & 33.05 & 32.82 & 28.41 & 27.80 & 29.02 & 28.74 \\
\hline $\mathrm{F}(\%)$ & 0.73 & 0.75 & 0.73 & 1.00 & 0.56 & 0.53 & 0.61 & 0.63 \\
\hline $\mathrm{Cl}(\%)$ & 0.85 & 0.73 & 0.68 & 0.67 & 0.66 & 0.58 & 0.58 & 0.53 \\
\hline $\mathrm{Al}(\%)$ & 4.12 & 3.87 & 3.68 & 3.55 & 5.05 & 4.96 & 4.77 & 4.77 \\
\hline $\mathrm{Mg}(\%)$ & 0.87 & 0.79 & 0.74 & 0.71 & 1.05 & 0.96 & 0.98 & 0.99 \\
\hline
\end{tabular}


(a)

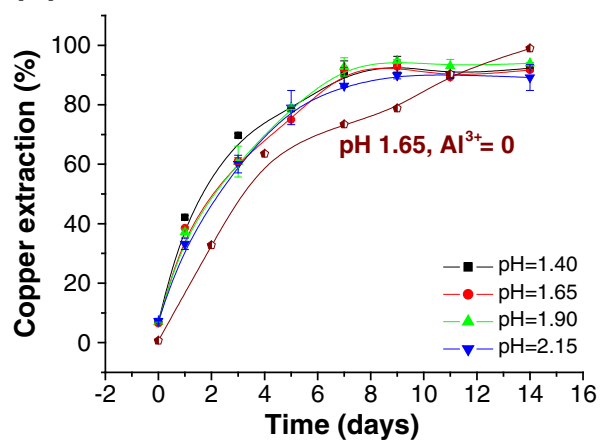

(c)

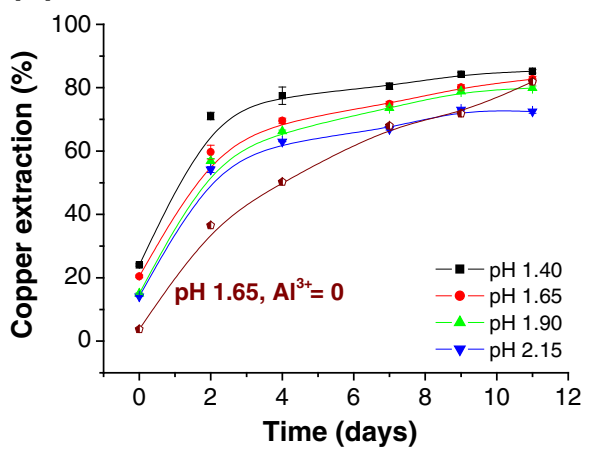

(b)

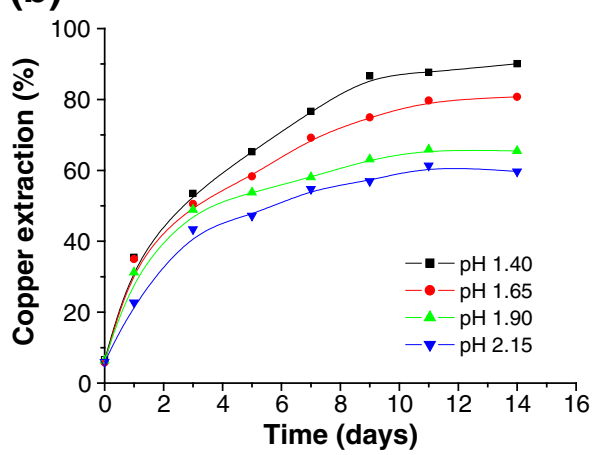

(d)

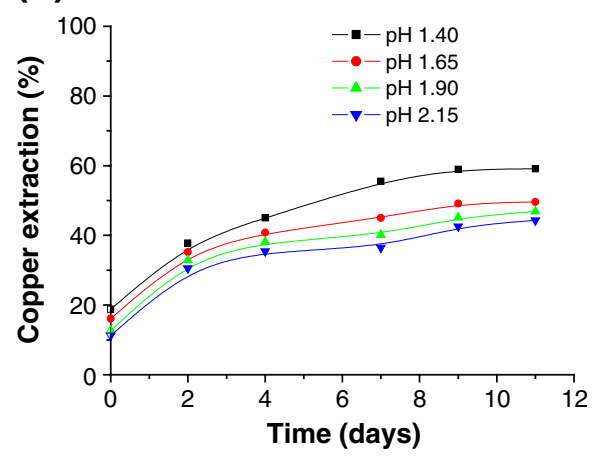

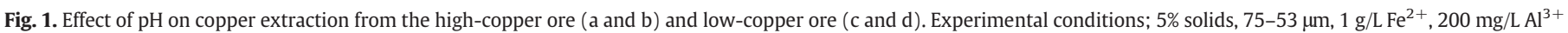

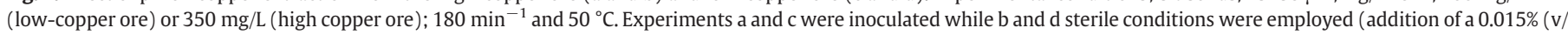
v) methylparaben $/ 0.01 \%(\mathrm{v} / \mathrm{v})$ propylparaben solution).

epoxy resin and then polished to a flat, mirrored surface. Energy dispersive X-ray spectroscopy (EDS) was used for elemental analysis.

\section{Results}

\subsection{Fluoride toxicity}

Initially, selected experiments followed the growth of S. thermosulfidooxidans in the presence of both the high- and low-grade copper ores since these secondary sulphides (chalcocite and bornite) are readily bioleached (Acevedo et al., 1993). Indeed, copper extraction was close to $100 \%$ and $80 \%$ with the high- and the low-grade copper ore, respectively, at pH 1.65 in 2 weeks (Fig. 1). However, the solution potential never reached values above $450 \mathrm{mV}(\mathrm{Ag} / \mathrm{AgCl})$ and the $\mathrm{Fe}^{2+}$ and $\mathrm{Fe}^{3+}$ concentrations were similar to those observed in the control experiments, i.e. all iron in solution $(2.0 \mathrm{~g} / \mathrm{L})$ was predominantly $\mathrm{Fe}^{2+}$. As $S$. thermosulfidooxidans is able to easily oxidize $\mathrm{Fe}^{2+}$, it was clear from the experiments that bacterial activity was impaired; taking the indirect mechanism as predominating in these systems.

Chalcocite is believed to be leached in two stages: (i) firstly, a rapid step where there is $50 \%$ copper extraction and a form of CuS is produced (the so-called second stage covellite); (ii) in the second stage the reaction is slower and more sensitive to both solution potential and temperature. At $35^{\circ} \mathrm{C}$ and $451 \mathrm{mV}$, for instance, Bolorunduro (1999) observed no more than 70\% copper extraction from chalcocite within 70 hours. Conversely, at $75^{\circ} \mathrm{C}$, extraction values larger than $70 \%$ could be observed, highlighting the positive effect of temperature on copper leaching from the second stage covellite. Therefore, the large copper extraction observed with the high-grade ore (100\%) in the present study could not be only ascribed to chemical leaching, although leaching at $50{ }^{\circ} \mathrm{C}$ is expected to be more efficient than at $35^{\circ} \mathrm{C}$. Overall, this result is consistent with bacterial leaching being impaired but not hindered completely, and a slow ferrous iron oxidation followed by a fast ferric iron reduction during copper sulphide oxidation would explain the low solution potential observed.

The reduced (or lack of) bacterial activity has been observed during bioleaching of many ores and has been ascribed in many instances to the deleterious effect of gangue minerals on bacterial activity (Dopson et al., 2008). While S. thermosulfidooxidans can tolerate up to $3 \mathrm{~g} / \mathrm{L} \mathrm{Cl}^{-}$(Gahan et al., 2009), fluoride is specially of concern as it predominates as $\mathrm{HF}$ at the given pulp $\mathrm{pH}$, which can cross cell membranes and lower internal cell pH (Suzuki et al., 1999). Actually, the presence of fluoride containing-minerals accounted for the failure of an industrial bioleaching operations (Brierley and Kuhn, 2010). In the present work, chemical analysis showed that chloride concentrations in solution were lower than $60 \mathrm{mg} / \mathrm{L}$, which is not detrimental to $S$. thermosulfidooxidans growth; however, fluoride concentrations reached $270 \mathrm{mg} / \mathrm{L}$ and $153 \mathrm{mg} / \mathrm{L}$, for both the highcopper and the low-copper ore, respectively. This high fluoride concentration is sufficient for bacterial growth inhibition, as similar concentrations affected chalcopyrite bioleaching with a mixed culture of mesophilic bacteria (Dopson et al., 2008).

Fluoride ions toxicity on bacterial growth can be overcome by the presence of soluble aluminium in the leaching systems (Brierley and Kuhn, 2010; Dopson et al., 2008; Sundkvist et al., 2005). This is because a series of strong complexes with the general formula $\left[\mathrm{AlF}_{\mathrm{n}}\right]^{3-\mathrm{n}}$, is formed by the two species, thereby reducing both the free fluoride and HF concentrations. Fig. 2 presents a series of results where solution potential (Eh) and bacterial counts were followed at different $\mathrm{Al} / \mathrm{F}$ molar ratios (in the absence of both ores) for a constant fluoride concentration $\left(10.5 \times 10^{-3} \mathrm{~mol} / \mathrm{L}\right)$ in the reactor. It can be observed that both cell counts and solution potential do not increase for $\mathrm{Al} / \mathrm{F}$ ratio equal or smaller than 1.0. Nevertheless, at aluminium - fluoride molar ratio of 1.4, the solution potential increases to $600 \mathrm{mV}$, and bacterial counts reach $10^{7}$ cells $/ \mathrm{mL}$. Therefore, copper bioleaching was affected in the aforementioned experiments, since fluoride released by the ore inhibited bacterial growth. Hence, in all 
(a)

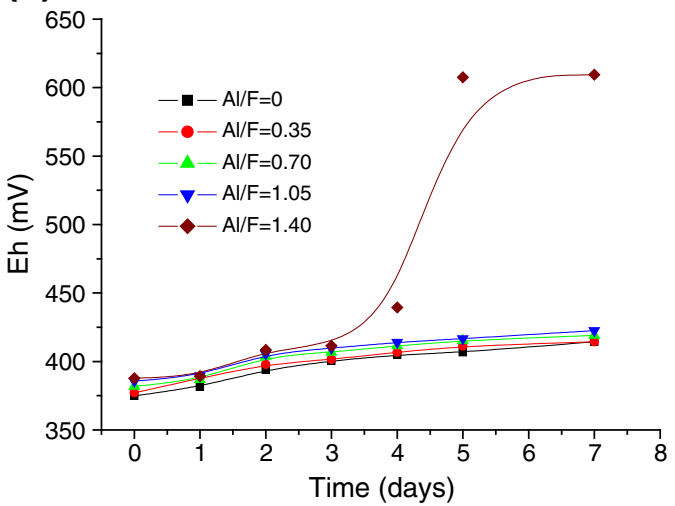

(b)

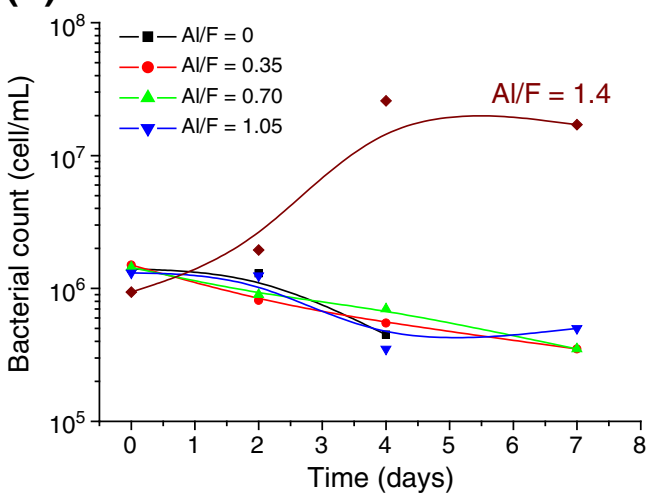

Fig. 2. Solution potential (a) and bacterial counts (b) for different $\mathrm{Al} / \mathrm{F}$ molar ratios. Initial fluoride concentration $10.5 \mathrm{mmol} / \mathrm{L}$; aluminium concentration was varied from 0 to $14.8 \mathrm{mmol} / \mathrm{L} ; 1 \mathrm{~g} / \mathrm{L} \mathrm{Fe}^{2+}, \mathrm{pH}=1.65,180 \mathrm{~min}^{-1}$ and $50{ }^{\circ} \mathrm{C}$.

(a)

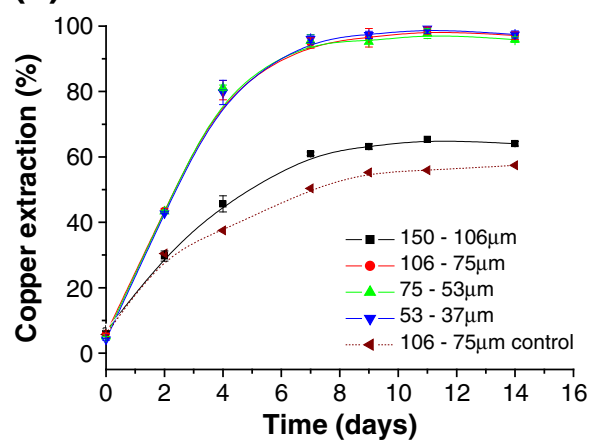

(c)

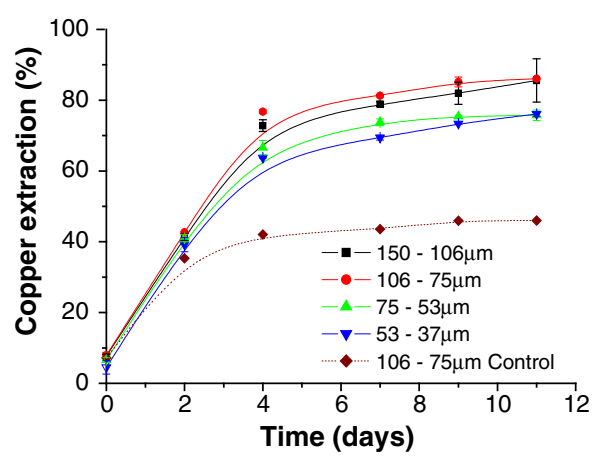

bioleaching experiments aluminium was added to the reaction systems ( $200 \mathrm{mg} / \mathrm{L}$ for the low-grade copper ore and $350 \mathrm{mg} / \mathrm{L}$ for the high-grade copper ore).

\subsection{Bioleaching parameters}

S. thermosulfidooxidans grows in the 1.1-2.4 $\mathrm{pH}$ range with optimum growth at pH 1.7-1.8 (Bogdanova et al., 2006), which corresponds to the fastest ferrous iron oxidation (Watling et al., 2008). Fig. 1 depicts the effect of $\mathrm{pH}$ on both the high-copper and lowcopper ore bioleaching in the $1.4-2.15 \mathrm{pH}$ range, at $50{ }^{\circ} \mathrm{C}$. In the experiments with the copper ore, copper extraction was accomplished in 6 days and no major effect of $\mathrm{pH}$ on copper yield was noticed (Fig. 1a). Nevertheless, in the control experiments, higher extraction was observed with increasing acidity, varying from $50 \%$ at pH 2.15 to $90 \%$ at pH 1.4 (Fig. 1b). With the low-grade copper ore, copper was leached within 3 days (Fig. 1c), but the extraction followed the pattern observed in the abiotic experiments (Fig. 1d), i.e. lower extraction at higher $\mathrm{pH}(85 \%$ extraction at $\mathrm{pH} 1.4$ and $72 \%$, at $\mathrm{pH}$ 2.15). Compared with the biotic experiments, bioleaching at $\mathrm{pH}$ 1.9 produces the largest gain in copper extraction, as a $30 \%$ improvement is noticed in biotic conditions. Similarly, Guo et al. (2010) observed the highest difference between chemical copper extraction and that with bacteria at $\mathrm{pH}$ 2.0. However, as $\mathrm{pH} 1.65$ showed overall higher copper extraction compared to that observed at $\mathrm{pH} 1.9$ (low-grade ore), it was chosen for the subsequent experiments.

Four different particle size ranges were studied during bioleaching i.e., $150-106 \mu \mathrm{m}, 106-75 \mu \mathrm{m}, 75-53 \mu \mathrm{m}$ and 53-37 $\mu \mathrm{m}$ and the results are shown in Fig. 3. For the high-copper ore, the largest particle size range (150-106 $\mu \mathrm{m})$ showed $60 \%$ extraction (30\% in the control) and the smallest particle size ranges depicted around 100\% leaching (30\% in the control); therefore the particle size ranges with bigger surface area showed higher extractions, as expected. Nevertheless, for the (b)

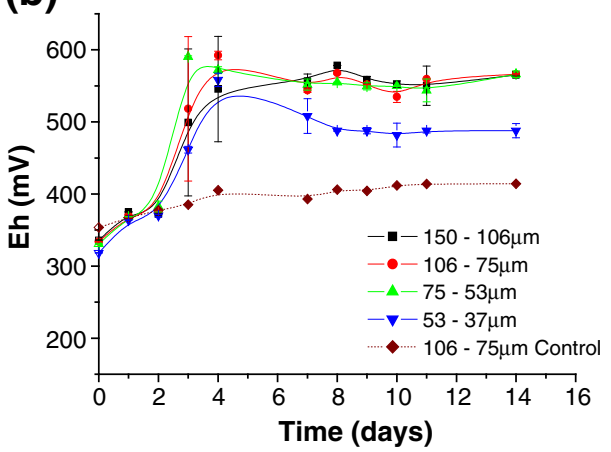

(d)

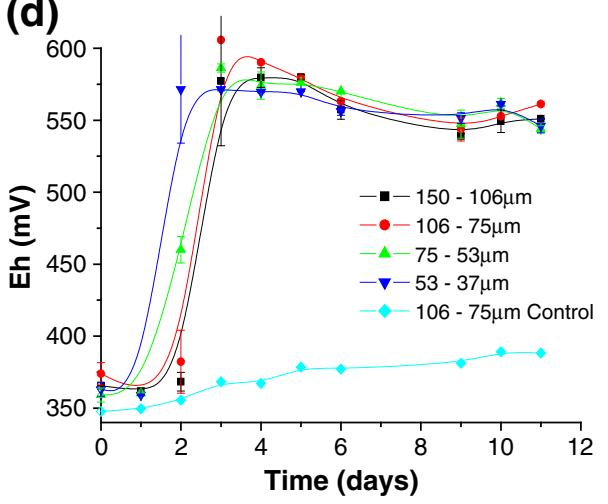

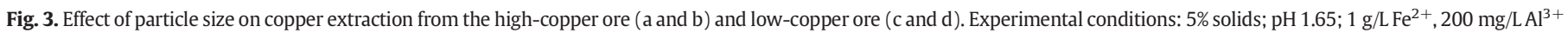
(low-copper ore) or $350 \mathrm{mg} / \mathrm{L}$ (high-copper ore); $180 \mathrm{~min}^{-1}$ and $50{ }^{\circ} \mathrm{C}$. In the control experiments, a $0.015 \%$ (v/v) methylparaben/0.01\% (v/v) propylparaben solution was present. 

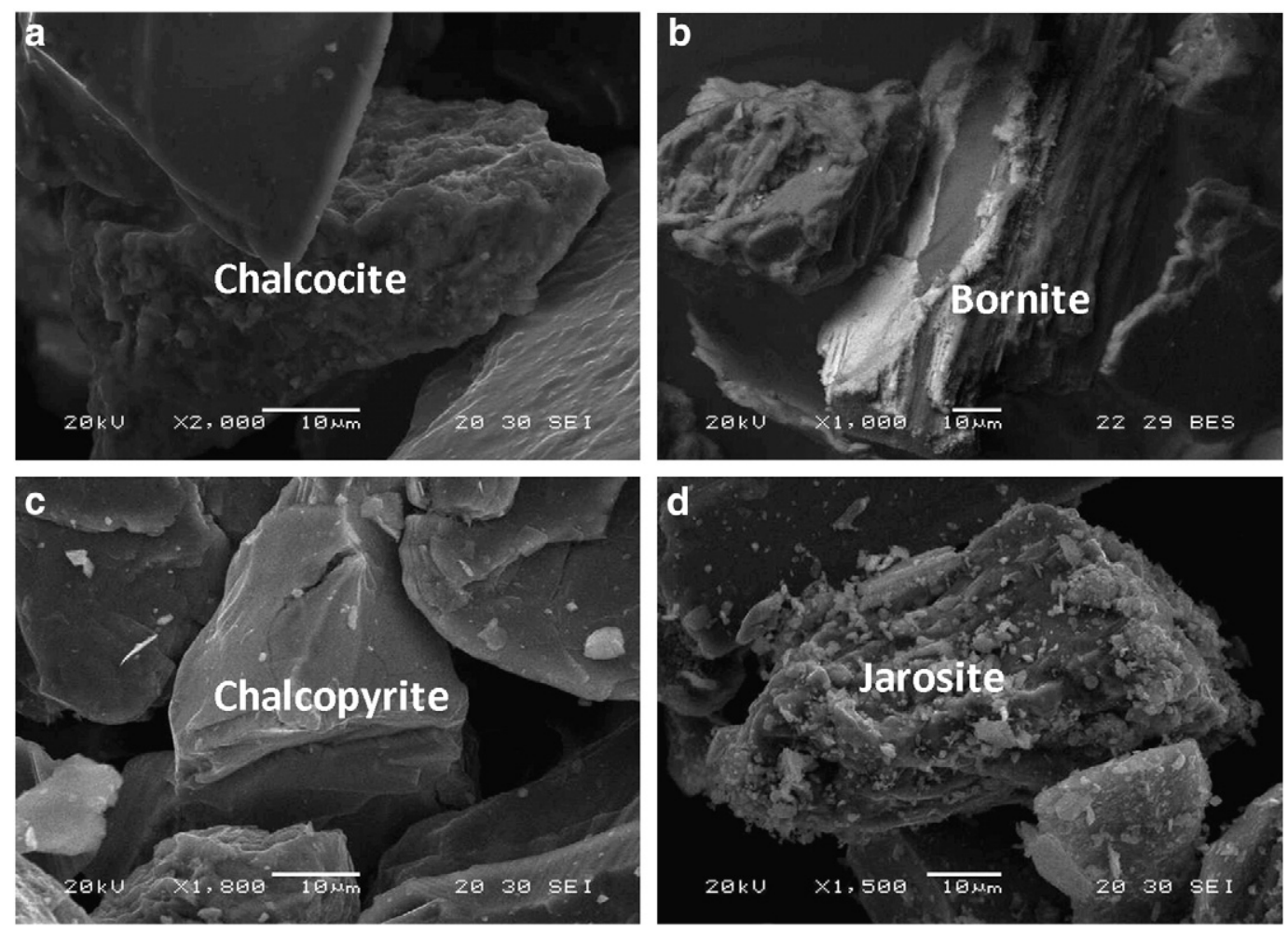

Fig. 4. SEM-EDS images of the high- (a) and low-copper (b) ores before leaching and the chemical leaching (c) and bioleaching (d) residues.

low-grade copper ore slightly higher extractions were observed for the larger particle sizes, $80 \%$ for the $150-106 \mu \mathrm{m}$ and $106-75 \mu \mathrm{m}$ ranges and $70 \%$ for the fractions with smaller particle sizes (75-53 $\mu \mathrm{m}$ and $53-37 \mu \mathrm{m})$. This unexpected higher extraction at larger particles size could be ascribed to a change on the ore mineralogy with particle size and is consistent with studies on particle size effects on zinc bioleaching from a mixed zinc-copper sulphide (Olubambi et al., 2007). This hypothesis could not be confirmed by MEV-EDS analysis as copper species were not observed in the leaching residues, likely due to the low metal content in these materials. They were identified only in the smallest particle size ranges, where copper content was the largest (Table 1). Chalcocite and bornite grains were noticed in both ores before leaching (Fig. 4a and b), whereas chalcopyrite was detected in the chemical leaching residue from the experiment with the low-grade copper ore (Fig. 4c). Conversely, only jarosite was observed in the bioleached residues (Fig. 4d) and resulted from ferrous iron oxidation as suggested by the high solution potential values observed (550-600 mV) in Figs. 4b and 3d. Elemental sulphur was not detected either in Fig. 4d and it may suggest it was oxidized by $S$. thermosulfidooxidans during sulphide bioleaching.

External ferrous iron was not required for bioleaching of either ore as copper extractions were close to $100 \%$ (high-grade copper ore) and $80 \%$ (low-grade copper ore), even when there was no external ferrous sulphate addition. Under these conditions, iron-containing phase dissolution resulted in some $1.2 \mathrm{~g} / \mathrm{L}$ total iron in solution, which is sufficient for bioleaching (Santos et al., 2006). When ferrous sulphate was added (1-10 g/L), in all bioleaching systems the ferric iron concentration was always lower than $2.0 \mathrm{~g} / \mathrm{L}$ due to substantial jarosite precipitation (Deveci et al., 2004; Qiu et al., 2006), especially in the experiments with larger initial ferrous iron concentrations $(10 \mathrm{~g} / \mathrm{L})$ (data not shown).

Heap leaching operations are designed to treat low-grade sources, such as the ores presently studied. In these operations, the barren solution is recirculated to the heap (or dump) after metal recovery and there is a built up of a series of metals, such as aluminium and magnesium, in the leaching liquor, which can impact bacterial growth, specially at high concentrations. This is because water activity is reduced at high ionic strengths, and therefore the cells lose water to the solution by an osmotic effect (Suzuki et al., 1999). This effect was studied varying the aluminium and magnesium concentrations separately in solution from 0 to $10 \mathrm{~g} / \mathrm{L}$, since both element concentrations can reach such values during industrial bioheap leaching (Ojumu et al., 2008). No significant effect was observed at lower concentrations, but at $10 \mathrm{~g} / \mathrm{L}$, magnesium and aluminium slowed copper leaching, although the final extractions were similar to those experiments where none were added (Fig. 5). The slower extraction was derived from the lower solution potentials, as the magnesium and aluminium concentrations increased (Fig. 6). Low magnesium concentrations are important for bacterial growth and it must be added to the solution if there is no magnesium-containing mineral in the ore. Conversely, aluminium is not required for bioleaching as it does not have metabolic functions, but due to the presence of soluble fluoride in the leaching system, the experiments where it was not added showed poorer leaching kinetics and the solution potential did not increase (Fig. $6 a$ and $b$ ) as compared to the experiments in the presence of $2.5 \mathrm{~g} / \mathrm{L} \mathrm{Al}^{3+}$ and $5.0 \mathrm{~g} / \mathrm{L} \mathrm{Al}^{3+}$. Therefore, for these two ores aluminium is required for bioleaching as previously discussed. These results are consistent with previous studies where aluminium was observed to affect, in any concentration, the ferrous iron oxidation rate by Leptospirillum ferriphilum whereas magnesium was detrimental only at concentrations higher than $10 \mathrm{~g} / \mathrm{L}$ (Ojumu et al., 2008). Similarly, magnesium affected A. ferrooxidans growth only at concentrations above $20 \mathrm{~g} / \mathrm{L}$ ( $\mathrm{Li}$ and $\mathrm{Ke}$, 2001).

Finally, a maximum copper extraction at $1 \%$ solids in an aerated stirred bioreactor was achieved after 3 to 4 days and was $100 \%$ with the high copper ore and $90 \%$ with the low copper ore, similar to that observed in the Erlenmeyer flasks. 
(a)

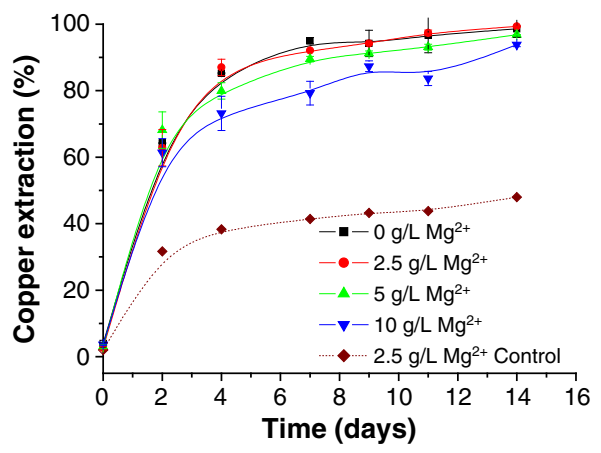

(c)

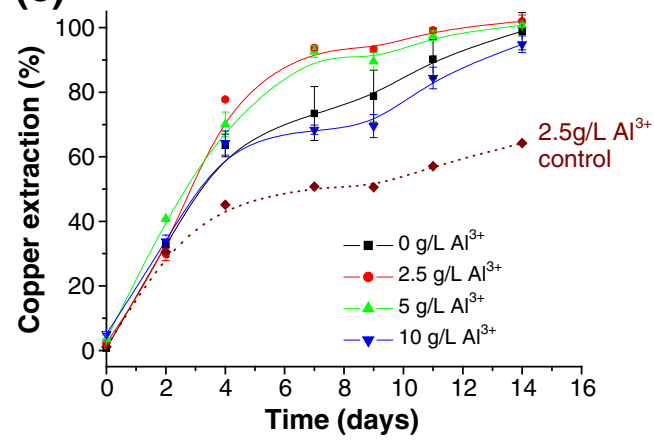

(b)

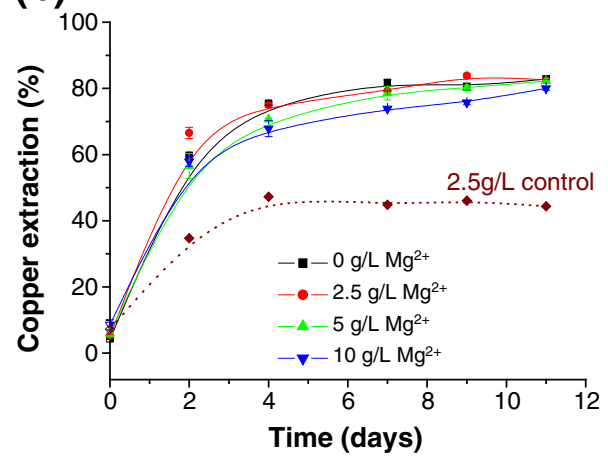

(d)

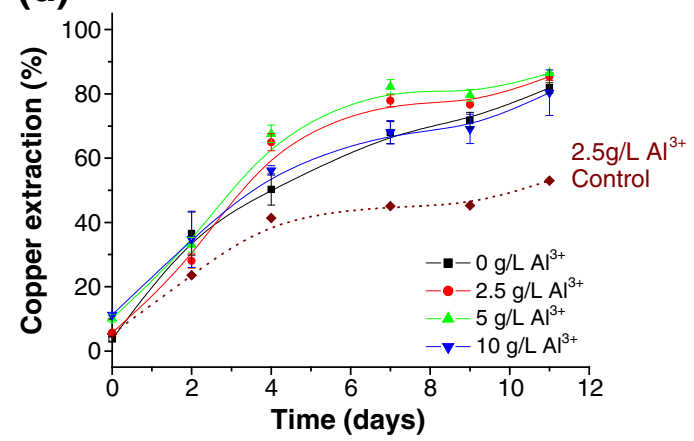

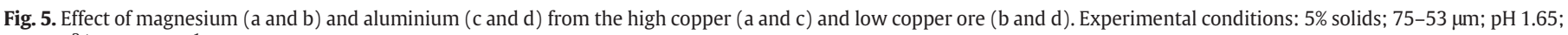
$1 \mathrm{~g} / \mathrm{L} \mathrm{Fe}^{2+} ; 180 \mathrm{~min}^{-1}$ and $50{ }^{\circ} \mathrm{C}$. In the control experiments, a $0.015 \%(\mathrm{v} / \mathrm{v}$ ) methylparaben/0.01\% (v/v) propylparaben solution was present.

(a)

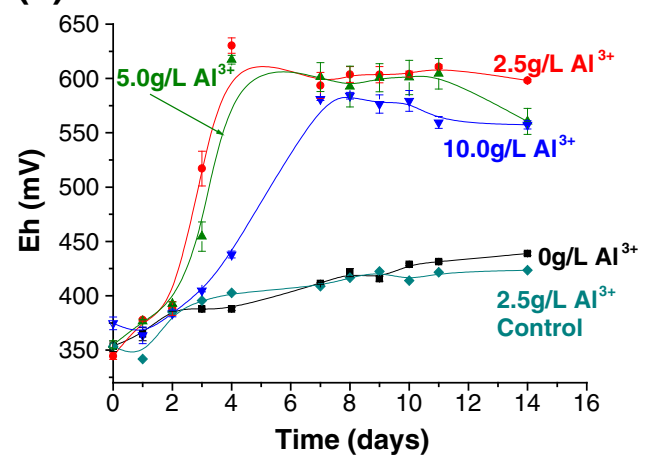

(c)

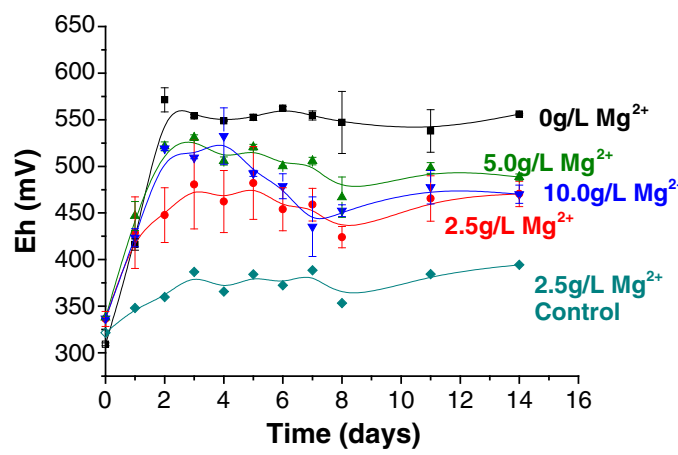

(b)

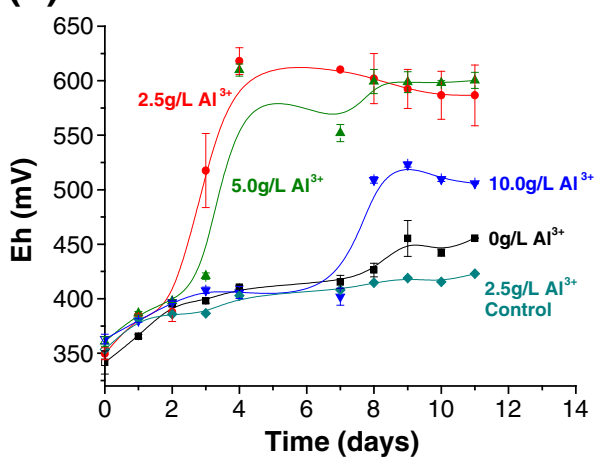

(d)

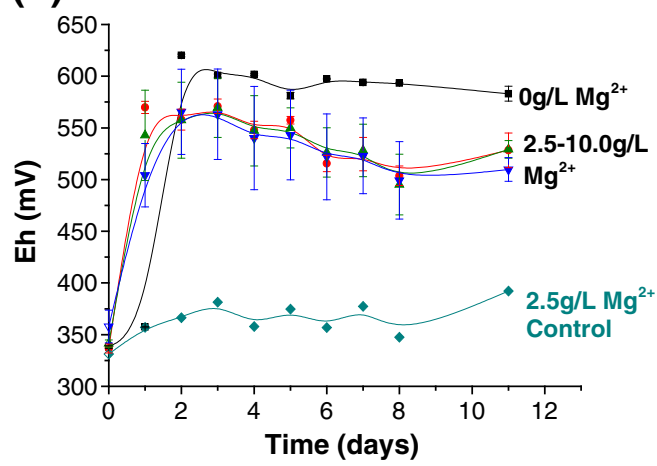

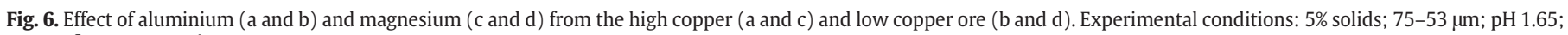
$1 \mathrm{~g} / \mathrm{L} \mathrm{Fe}^{2+} ; 180 \mathrm{~min}^{-1}$ and $50{ }^{\circ} \mathrm{C}$. In the control experiments, a $0.015 \%(\mathrm{v} / \mathrm{v})$ methylparaben/0.01\% (v/v) propylparaben solution was present. 
Table 2

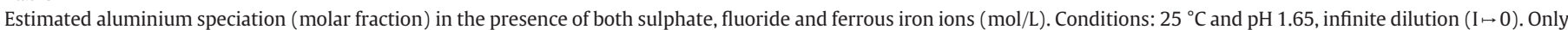
the depicted species were considered in the calculations. Total concentrations: $10.5 \times 10^{-3} \mathrm{~mol} / \mathrm{L}$ (fluoride); $40.2 \times 10^{-3} \mathrm{~mol} / \mathrm{L}$ (sulfate); $17.9 \times 10^{-3} \mathrm{~mol} / \mathrm{L}$ (ferrous iron).

\begin{tabular}{|c|c|c|c|c|c|}
\hline $\mathrm{Al} / \mathrm{F}$ & 0.35 & 0.7 & 1.05 & 1.40 & Remarks \\
\hline $\mathrm{F}^{-}$ & $1.59 \times 10^{-4}$ & $9.76 \times 10^{-6}$ & $4.57 \times 10^{-6}$ & $2.64 \times 10^{-6}$ & \\
\hline $\mathrm{HF}$ & $5.64 \times 10^{-3}$ & $3.46 \times 10^{-4}$ & $1.62 \times 10^{-4}$ & $9.38 \times 10^{-5}$ & $\mathrm{pKa}=3.2$ \\
\hline $\mathrm{Al}^{3+}$ & $1.13 \times 10^{-7}$ & $8.13 \times 10^{-5}$ & $2.85 \times 10^{-5}$ & $6.36 \times 10^{-5}$ & \\
\hline $\mathrm{AlF}^{2+}$ & $7.16 \times 10^{-4}$ & $3.16 \times 10^{-2}$ & $5.18 \times 10^{-3}$ & $6.69 \times 10^{-3}$ & $\log \beta_{1}=7.0$ \\
\hline $\mathrm{AlF}_{2}^{+}$ & $1.14 \times 10^{-2}$ & $3.08 \times 10^{-2}$ & $2.37 \times 10^{-3}$ & $1.77 \times 10^{-3}$ & $\log \beta_{2}=12.6$ \\
\hline $\mathrm{AlF}_{3}$ & $2.28 \times 10^{-2}$ & $3.79 \times 10^{-3}$ & $1.36 \times 10^{-4}$ & $5.88 \times 10^{-5}$ & $\log \beta_{3}=16.7$ \\
\hline $\mathrm{AlF}_{4}^{-}$ & $1.82 \times 10^{-3}$ & $1.85 \times 10^{-5}$ & $3.13 \times 10^{-7}$ & $7.79 \times 10^{-8}$ & $\log \beta_{4}=19.4$ \\
\hline $\mathrm{AlSO}_{4}^{+}$ & $9.81 \times 10^{-6}$ & $4.89 \times 10^{-3}$ & $2.10 \times 10^{-3}$ & $4.06 \times 10^{-3}$ & $\log \beta_{1}=3.5$ (Gimeno Serrano et al., 2000) \\
\hline $\mathrm{Al}\left(\mathrm{SO}_{4}\right)_{2}^{-}$ & $6.75 \times 10^{-6}$ & $2.33 \times 10^{-3}$ & $1.23 \times 10^{-3}$ & $2.06 \times 10^{-3}$ & $\log \beta_{2}=4.9$ (Gimeno Serrano et al., 2000) \\
\hline $\mathrm{FeSO}_{4}^{0}$ & $1.46 \times 10^{-2}$ & $1.34 \times 10^{-2}$ & $1.41 \times 10^{-2}$ & $1.36 \times 10^{-2}$ & $\log \beta_{1}=2.4$ \\
\hline $\mathrm{Fe}^{2+}$ & $3.35 \times 10^{-3}$ & $4.46 \times 10^{-3}$ & $3.81 \times 10^{-3}$ & $4.26 \times 10^{-3}$ & \\
\hline
\end{tabular}

\section{Discussion}

Secondary sulphides are amenable to bioleaching and many industrial operations apply this technology to produce copper (Brierley, 2008). During secondary copper sulphides bioleaching with $S$. thermosulfidooxidans, high copper extraction associated with high solution potentials was expected as this bacterium readily oxidizes $\mathrm{Fe}^{2+}$ ions. Nevertheless, while high copper extraction was achieved in two weeks, the solution potential never increased, pointing to slow ferrous iron bio-oxidation i.e. bacterial growth was affected. With the help of mineralogical analysis it was possible to identify a possible explanation for the reduced bacterial activity in these systems. Fluoride, which was present in both the high-grade copper and the low-grade copper ore, was detected in fairly large concentrations as fluorite, and its dissolution released high total fluoride concentrations in solution.

Many studies have shown the detrimental effects of fluoride on bacterial growth, ascribed to the predominance of the HF form at the $\mathrm{pH}$ of bioleaching. Acidophiles maintain a neutral cytoplasmic $\mathrm{pH}$, which is $4-5$ units above external solution $\mathrm{pH}$. To achieve that, the cytoplasmic membrane (a lipid bilayer), despite allowing flow of ions and molecules to support metabolism, must hinder protons from entering the cell. This is a specialized process because protons cross the membrane easier than any other monovalent cations. The entry of protons is further reduced by an inverted trans-membrane potential $(\Delta \Psi)$, which also contributes to the neutral cytoplasmic $\mathrm{pH}$ (Slonczewski et al., 2009). HF, the main fluoride species at acidic $\mathrm{pH}$, is uncharged and small enough to cross the bacterial cell membrane and is converted to both free fluorine ions $\left(\mathrm{F}^{-}\right)$and protons $\left(\mathrm{H}^{+}\right)$inside the cell, reducing its internal $\mathrm{pH}$ (Suzuki et al., 1999). This is consistent with the observation that HF permeability is seven orders of magnitude higher than that of fluoride ions $\left(\mathrm{F}^{-}\right)$on synthetic lipid bilayers (Gutknecht and Walter, 1981).

Table 2 gives the calculated concentrations of the main aluminium-fluoride complexes at the experimental conditions described in Fig. 2 ( $\mathrm{pH} 1.65$, without the presence of solids), at $25^{\circ} \mathrm{C}$ and infinite dilution, with data provided by both the NIST database (Martel and Smith, 2003) and by Gimeno Serrano et al. (2000). These calculations apply to the beginning of those experiments where $\mathrm{Fe}^{2+}$ was the main iron species and ferric iron concentrations were low enough to affect the concentration of the aluminium-fluoride species. The aluminium sulphate complexes $\mathrm{AlSO}_{4}^{+}$and $\mathrm{Al}\left(\mathrm{SO}_{4}\right)^{-}$were also included in the calculations since sulphate is present in high concentrations (as compared to fluoride) in this system.

Although actual values are somewhat different, due to the different bioleaching temperature and ionic strength, the results from Table 2 suggests AlF $^{2+}$ as the main complex at aluminium/ fluoride molar ratio larger than 0.70 , unlike $\mathrm{AlF}_{2}{ }^{+}$, which was proposed to be the dominating complex by Sundkvist et al. (2005). In the experimental conditions of the present work and for the aluminium/fluoride ratio that enabled bacterial growth $(\mathrm{Al} / \mathrm{F}=1.4)$, $\mathrm{AlF}^{2+}$ represented $45.5 \%$ whereas $\mathrm{AlF}_{2}^{+}$species account for $12.0 \%$ and $\mathrm{AlSO}_{4}{ }^{+}$, for $27.6 \%$ of the fluoride-containing species in the system. The predominance of $\mathrm{AlF}^{2+}$ is consistent with the findings of Brierley and Kuhn (2010). Nevertheless, HF is the species that affects bacterial growth. Table 2 also shows an increase in the HF concentration as the $\mathrm{Al} / \mathrm{F}$ molar ratio decreases, ranging from $9.4 \times 10^{-5} \mathrm{~mol} / \mathrm{L}$ at $\mathrm{Al} / \mathrm{F}=1.4$ to $5.6 \times 10^{-3} \mathrm{~mol} / \mathrm{L}$ at $\mathrm{Al} / \mathrm{F}=0.35$. Therefore, $10^{-4} \mathrm{~mol} / \mathrm{L}$ seems to be the threshold for bacterial growth inhibition. This low limit would explain the detrimental effects of flouride during chalcopyrite heapbioleaching, as much higher HF concentration, varying from $0.14 \times 10^{-3}$ to $1.79 \times 10^{-3} \mathrm{~mol} / \mathrm{L}$, were calculated in the work of Dopson et al. (2008). However, the stability constants of the aluminium-fluoride complexes applied by Sundkvist et al. (2005) were significantly lower than the values reported in both the NIST database and in the work of Gimeno Serrano et al. (2000) (Table 2), which may had led to the different results.

Once the detrimental effects of fluoride have been overcome, bioleaching can be performed provided external aluminium sources are present as the experiments starts. This is important because iron is initially present as $\mathrm{Fe}^{2+}$, which, unlike $\mathrm{Fe}^{3+}$, does not form strong complexes with fluoride ions. Bioleaching kinetics in the presence of both fluoride and aluminium were faster as compared to the experiments without the metallic ion. Maximum copper extraction was attained in 6 and 3 days for the high-grade copper and low-grade copper ores, respectively, whereas in the absence of aluminium 14 and 12 days, respectively, were required for the same extractions (Fig. 1, pH 1.65). If an external aluminium source is not added, it would be required aluminium leaching from the ore to produce metal concentrations capable of significant fluoride complexation. This would explain the faster copper leaching kinetics from the 7th to the 9th day onward shown in Figs. 1a and 4c.

During bioleaching the $\mathrm{pH}$ can be set at high values as compared to that required for chemical leaching (control). While at the latter condition higher extractions were observed at lower $\mathrm{pH}$ (1.4), with an expected higher acid consumption (not determined), bioleaching enables copper extraction at higher $\mathrm{pH}$, which has important implications for process economics. These results are consistent with heap bioleaching studies (columns), which observed substantial reduction in acid consumption as the solution $\mathrm{pH}$ was increased

Table 3

Values of cyanide-soluble copper content in the different particle size ranges of the low-grade ore before bioleaching.

\begin{tabular}{ll}
\hline Particle size & Cyanide soluble copper (\%) \\
\hline $150-106 \mu \mathrm{m}$ & 75.54 \\
$106-75 \mu \mathrm{m}$ & 72.67 \\
$75-53 \mu \mathrm{m}$ & 66.90 \\
$53-37 \mu \mathrm{m}$ & 61.42 \\
\hline
\end{tabular}


(Dopson et al., 2009; Halinen et al., 2009). Acid consumption during bioleaching will be assessed in future column experiments.

The bio-leaching of the low-grade copper ore was affected by particle size, with unexpectedly higher extractions for the two coarser ranges. This effect can be explained by considering the mineralogical composition of the low-copper ore, which contains chalcopyrite that is not amenable to leaching by moderate thermophiles (Xia et al., 2010). As shown in Table 1, copper content is larger in the finer particle size ranges and the chalcopyrite content could have also increased in this finer fractions. This is consistent with previous studies, which also showed that metal content changes with particle size (Antonijevic et al., 2008; Torrisi, 2001), but mostly these changes did not impact leaching yields (Kaewkannetra et al., 2009; Nemati et al., 2000), as observed in this work. Higher copper content of finer particle size ranges were also observed in a study addressing flotation tailings leaching (Antonijevic et al., 2008), but the copper mineralogy, comprised mainly of covellite, did not change with particle size, and higher copper extractions were observed for the finer fractions, as expected. In the present work, attempts to identify chalcopyrite in the leaching residues were unsuccessful. However, an indirect estimate of chalcopyrite content can be performed by measuring the amount of cyanide-soluble copper in the 4 particle size ranges studied. While bornite and chalcocite are readily dissolved in cyanide, chalcopyrite is considered non cyanide-soluble (Leaver and Wolf, 1931). For the smaller particle size, the cyanide-soluble copper content is smaller (Table 3), thereby suggesting that the insoluble copper phases content (mostly chalcopyrite) is larger. That implies in a change on copper mineralogy with particle size for the low copper ore, as also observed by Olubambi et al. (2007) and Dew et al. (2000).

Bioleaching seems to be a suitable option to recover metallic content from low-grade copper sources, potentially reducing environmental impacts of toxic metals. Moreover, acid mine drainage generated from mining residues is a slow process that can last for decades and pollute waters with metals and sulphate (acid and neutral drainages) as well as acidity (acid drainage). Once started, these processes are hard to stop. Bioleaching can be an viable option to deal with sulphide-containing mining wastes because it accelerates sulphide oxidation in a controlled way, enabling metal recovery from solution and this metallic content can be economically recovered and applied to cover costs associated with solid waste disposal as well as mining water treatment. This work is being conducted through column experiments where the best bioleaching parameters with S. thermosulfidooxidans will be established, with special attention to fluoride and aluminium build-up in the leach solution, as well as acid consumption.

\section{Conclusions}

Fluoride presence in both the high-grade copper and the lowgrade copper ores had a negative impact on copper bioleaching from secondary sulphides (chalcocite and bornite). Fluoride toxicity was removed with aluminium additions that enabled the production of $\mathrm{AlF}^{2+}$ complexes and reduced the HF concentration to values below $10^{-4} \mathrm{~mol} / \mathrm{L}$, which seems to be the threshold for bacterial growth inhibition. To achieve this, the minimum Al/F molar ratio should be 1.4. The best parameters for copper bioleching with Sulfobacillus thermosulfidooxidans from both materials were defined as particle size below $106 \mu \mathrm{m}, 350 \mathrm{mg} / \mathrm{L} \mathrm{Al}^{3+}$, for the high-copper ore and the particle size range $150-75 \mu \mathrm{m}, 200 \mathrm{mg} / \mathrm{L} \mathrm{Al}^{3+}$, for the low-copper ore. For both ores, a pH value of 1.90 showed the best results as compared with the control experiments. External $\mathrm{Fe}^{2+}$ additions were not required for bioleaching, while high concentrations $(10 \mathrm{~g} / \mathrm{L})$ of either $\mathrm{Mg}^{2+}$ or $\mathrm{Al}^{3+}$ slowed copper extraction. Copper extraction from both ores at $50{ }^{\circ} \mathrm{C}$ can be carried out at $\mathrm{pH}$ values as high as 2.15 , while for attaining similar extractions with chemical leaching the $\mathrm{pH}$ should be 1.4. Therefore bioleaching enables copper extractions with lower acid consumption. From a heap-bioleaching perspective, the PLS enrichment of fluoride and aluminium should be followed carefully since they can result in reduced operation performance.

\section{Acknowledgements}

The financial support from the funding agencies FINEP, FAPEMIG, CNPq, and CAPES as well as Vale is gratefully appreciated. The "Conselho Nacional de Pesquisas - CNPq scholarships to L. C. Sicupira, T. C. Veloso and V. A. Leão are especially acknowledged.

\section{References}

Acar, S., Brierley, J.A., Wan, R.Y., 2005. Conditions for bioleaching a covellite-bearing ore. Hydrometallurgy 77 (3-4), 239-246. doi:10.1016/j.hydromet.2004.05.004.

Acevedo, F., Gentina, J.C., Bustos, S., 1993. Bioleaching of minerals - a valid alternative for developing countries. Journal of Biotechnology 31 (1), 115-123. doi:10.1016/ 0168-1656(93), 90141-9.

Antonijevic, M.M., Dimitrijevic, M.D., Stevanovic, Z.O., Serbula, S.M., Bogdanovic, G.D., 2008. Investigation of the possibility of copper recovery from the flotation tailings by acid leaching. Journal of Hazardous Materials 158 (1), 23-34. doi:10.1016/j. jhazmat.2008.01.063.

Bogdanova, T.y.I., Tsaplina, I.A., Kondrat'eva, T.F., Duda, V.I., Suzina, N.E., Melamud, V.S., Tourova, T.y.P., Karavaiko, G.I., 2006. Sulfobacillus thermotolerans sp. nov., a thermotolerant, chemolithotrophic bacterium. International Journal of Systematic and Evolutionary Microbiology 56 (5), 1039-1042. doi:10.1099/ijs.0.64106-0.

Bolorunduro, S.A., 1999. Kinetics of leaching of chalcocite in acid ferric sulfate media: chemical and bacterial leaching. University of British Columbia, Vancouver. 176 pp.

Brierley, J.A., 2008. A perspective on developments in biohydrometallurgy. Hydrometallurgy 94 (1-4), 2-7. doi:10.1016/j.hydromet.2008.05.014.

Brierley, J.A., Kuhn, M.C., 2010. Fluoride toxicity in a chalcocite bioleach heap process. Hydrometallurgy 104 (3-4), 410-413. doi:10.1016/j.hydromet.2010.01.013.

Deveci, H., Akeil, A., Alp, I., 2004. Bioleaching of complex zinc sulphides using mesophilic and thermophilic bacteria: comparative importance of $\mathrm{pH}$ and iron. Hydrometallurgy 73, 293-303.

Dew, D., Buuren, C.V., McEwan, K., Bowker, C., 2000. Bioleaching of base metal sulphide concentrates: a comparison of high and low temperature bioleaching. The Journal of the South African Institute of Mining and Metallurgy 100 (7), 409-414.

Dopson, M., Halinen, A.-K., Rahunen, N., Boström, D., Sundkvist, J.-E., RiekkolaVanhanen, M. Kaksonen, A.H., Puhakka, J.A., 2008. Silicate mineral dissolution during heap bioleaching. Biotechnology and Bioengineering 99 (4), 811-820. doi:10.1002/bit.21628.

Dopson, M., Lövgren, L., Boström, D., 2009. Silicate mineral dissolution in the presence of acidophilic microorganisms: implications for heap bioleaching. Hydrometallurgy 96 (4), 288-293. doi:10.1016/j.hydromet.2008.11.004.

Gahan, C.S., Sundkvist, J.-E., Sandström, Å., 2009. A study on the toxic effects of chloride on the biooxidation efficiency of pyrite. Journal of Hazardous Materials 172 (2-3), 1273-1281. doi:10.1016/j.jhazmat.2009.07.133.

Gimeno Serrano, M.J., Auqué Sanz, L.F., Nordstrom, D.K., 2000. REE speciation in lowtemperature acidic waters and the competitive effects of aluminum. Chemical Geology 165 (3-4), 167-180. doi:10.1016/s0009-2541(99), 00166-7.

Guo, Z., Zhang, L., Cheng, Y., Xiao, X., Pan, F., Jiang, K., 2010. Effects of pH, pulp density and particle size on solubilization of metals from a $\mathrm{Pb} / \mathrm{Zn}$ smelting slag using indigenous moderate thermophilic bacteria. Hydrometallurgy 104 (1), 25-31. doi:10.1016/j.hydromet.2010.04.006.

Gutknecht, J., Walter, A., 1981. Hydrofluoric and nitric acid transport through lipid bilayer membranes. Biochimica et Biophysica Acta (BBA) - Biomembranes 644 (1), 153-156. doi:10.1016/0005-2736(81)90071-7.

Habashi, F., 1993. A Textbook of Hydrometallurgy. Métallurgie Extractive Quebec, Quebec. 689 pp.

Halinen, A.K., Rahunen, N., Kaksonen, A.H., Puhakka, J.A., 2009. Heap bioleaching of a complex sulfide ore Part I: Effect of $\mathrm{pH}$ on metal extraction and microbial composition in $\mathrm{pH}$ controlled columns. Hydrometallurgy 98 (1-2), 92-100. doi:10.1016/j.hydromet.2009.04.005.

Kaewkannetra, P., Garcia-Garcia, F.J., Chiu, T.Y., 2009. Bioleaching of zinc from gold ores using Acidithiobacillus ferrooxidans. International Journal of Minerals, Metallurgy, and Materials 16 (4), 368-374. doi:10.1016/s1674-4799(09), 60066-2.

Leaver, E.S., Wolf, J.A., 1931. Copper and Zinc in Cyanidation Sulfide Acid Precipitation. US Bureau of Mines Technical Paper No. 494.

Lee, J., Acar, S., Doerr, D.L., Brierley, J.A., 2011. Comparative bioleaching and mineralogy of composited sulfide ores containing enargite, covellite and chalcocite by mesophilic and thermophilic microorganisms. Hydrometallurgy 105 (3-4), 213-221. doi:10.1016/j.hydromet.2010.10.001.

Li, H.M., Ke, J.J., 2001. Influence of $\mathrm{Ni}^{2+}$ and $\mathrm{Mg}^{2+}$ on the growth and activity of $\mathrm{Cu}^{2+}$ adapted Thiobacillus ferrooxidans. Hydrometallurgy 61 (3), 151-156. doi:10.1016/ s0304-386x(01)00167-0.

Martel, A.E., Smith, R.M., 2003. NIST critically selected stability constants of metals complexes. The National Institute of Standards and Technology - NIST, Gaithersburg.

Nemati, M., Lowenadler, J., Harrison, S.T.L., 2000. Particle size effects in bioleaching of pyrite by acidophilic thermophile Sulfolobus metallicus (BC). Applied Microbiology and Biotechnology 53 (2), 173-179. doi:10.1007/s002530050005. 
Ojumu, T.V., Petersen, J., Hansford, G.S., 2008. The effect of dissolved cations on microbial ferrous-iron oxidation by Leptospirillum ferriphilum in continuous culture. Hydrometallurgy 94 (1), 69-76. doi:10.1016/j.hydromet.2008.05.047.

Olson, G.J., Clark, T.R., 2001. Bioleaching of a mixed copper sulfide ore containing enargite and luzonite. In: Cimininelli, V.S.T., Garcia Jr., O. (Eds.), International Biohydrometallurgy Symposium. Elsevier, Ouro Preto, Brazil, pp. 543-551.

Olubambi, P.A., Ndlovu, S., Potgieter, J.H., Borode, J.O., 2007. Effects of ore mineralogy on the microbial leaching of low grade complex sulphide ores. Hydrometallurgy 86 (1-2), 96-104. doi:10.1016/j.hydromet.2006.10.008.

Qiu, M., Wang, G., Zhang, W., Xiong, S., 2006. Optimizing conditions for bacterial leaching of copper from discarded mines. Journal of University of Science and Technology Beijing, Mineral, Metallurgy, Material 13 (2), 108-111. doi:10.1016/ s1005-8850(06), 60024-8.

Santos, L.R.G., Barbosa, A.F., Souza, A.D., Leao, V.A., 2006. Bioleaching of a complex nickel-iron concentrate by mesophile bacteria. Minerals Engineering 19 (12), 1251-1258. doi:10.1016/j.mineng.2006.03.001.

Schippers, A., Von Rège, H., Sand, W., 1996. Impact of microbial diversity and sulfur chemistry on safeguarding sulfudic mine waste. Minerals Engineering 9 (10), 1069-1079. doi:10.1016/0892-6875(96), 00099-4.

Slonczewski, J.L., Fujisawa, M., Dopson, M., Krulwich, T.A., 2009. Cytoplasmic pH measurement and homeostasis in bacteria and archaea. Advances in Microbial Physiology 55 (1-79).
Sundkvist, J.E., Sandström, Å., Gunneriusson, L., Lindström, E.B., 2005. Fluorine toxicity in bioleaching systems. In: Harrison, S.T.L., Rawlings, D.E., Petersen, J. (Eds.), International Biohydrometallurgy Symposium. Elsevier, Cape Town, South Africa, pp. 19-28.

Suzuki, I., Lee, D., Mackay, B., Harahuc, L., Oh, J.K., 1999. Effect of various ions, pH, and osmotic pressure on oxidation of elemental sulfur by Thiobacillus thiooxidans. Applied and Environmental Microbiology 65 (11), 5163-5168.

Torrisi, C., 2001. Leaching of fluorine bearing minerals from lead and zinc concentrates. Minerals Engineering 14 (12), 1637-1648. doi:10.1016/s0892-6875(01), 00182-0.

Watling, H.R., Perrot, F.A., Shiers, D.W., 2008. Comparison of selected characteristics of Sulfobacillus species and review of their occurrence in acidic and bioleaching environments. Hydrometallurgy 93 (1-2), 57-65. doi:10.1016/j.hydromet.2008. 03.001.

Witne, J.Y., Phillips, C.V., 2001. Bioleaching of Ok Tedi copper concentrate in oxygenand carbon dioxide- enriched air. Minerals Engineering 14 (1), 25-48. doi:10.1016 S0892-6875(00), 00158-8.

Xia, J.L., Yang, Y., He, H., Liang, C.L., Zhao, X.J., Zheng, L., Ma, C.Y., Zhao, Y.D., Nie, Z.Y., Qiu, G.Z., 2010. Investigation of the sulfur speciation during chalcopyrite leaching by moderate thermophile Sulfobacillus thermosulfidooxidans. International Journal of Mineral Processing 94 (1-2), 52-57. doi:10.1016/j.minpro.2009.11.005. 